\title{
Cognition improving effect of the compositions prepared with extracts of Wongam, Sorghum bicolor (L.) Moench and pupae of Bombyx mori L.
}

\author{
Seung-Eun Lee ${ }^{1 *}$, Saet-Byul Park ${ }^{1}$, Hae-Yong Kweon ${ }^{2}$, Jeong-Yong Park ${ }^{1}$, Ji-Yeon Lee ${ }^{1}$, \\ You-Young $\mathrm{Jo}^{2}$, Jeonghoon Lee ${ }^{1}$, Gwi-Yeong Jang ${ }^{1}$, Su-Ji Choi ${ }^{1}$, Dong-Hwi Kim ${ }^{1}$ \\ ${ }^{1}$ Department of Herbal Crop Research, National Institute of Horticultural \& Herbal Science, RDA, \\ Eumseong 27709, Korea \\ ${ }^{2}$ Department of Agricultural Biology, National Institute of Agricultural Sciences, RDA, Wanju 55365, Korea
}

\section{원감, 수수 및 누에번데기 추출물로 조제된 조성물의 인지기능 개선 효과 \\ 이승은 ${ }^{1 *} \cdot$ 박샛별 $^{1} \cdot$ 권해용 $^{2} \cdot$ 박정용 $^{1} \cdot$ 이지연 $^{1} \cdot$ 조유영 $^{2} \cdot$ 이정훈 ${ }^{1} \cdot$ 장귀영 $^{1} \cdot$ 최수지 $^{1} \cdot$ 김동휘 $^{1}$ \\ 1농촌진흥청 국립원예특작과학원 인삼특작부, ${ }^{2}$ 농촌진흥청 국립농업과학원 농업생물부}

\begin{abstract}
Dementia including Alzheimer's disease, is a severe neurodegenerative disorder characterized by progressive cognitive deficits as major symptom. The compositions (BBGS171) including extracts from root of Wongam (a Glycyrriza cultivar), seed of Sorghum bicolor (L.) pupae of Moench and Bombyx mori L. was selected based on preliminary experiments on the ability to improve cognition function in vitro. BBGS171 showed inhibitory activity on cholinesterases, such as acetylcholinesterase (AChE) and butyrylcholinesterase (BuchE) and inhibited nitric oxide (NO) production in lipopolysaccharide (LPS)-treated BV2 cells (a microglial cell line). The Y-maze test and passive avoidance test (PAT) were used to evaluate the behavior of an animal model of scopolamine-induced cognitive impairment. Rats administered BBGS171 (EM, extract mixture) in the diet showed better spontaneous alteration and escape latency than those of control rats. Levels of hippocampal choline acetyltransferase (ChAT) and serum acetylcholine (ACh) were significantly higher in the BBGS171 diet group than in the control group. Expression levels of brain-derived neurotrophic factor (BDNF) and extracellular signal-regulated kinase (ERK) 1/2 in the hippocampus of the BBGS171 diet group were also higher than those of control group. These results suggest that BBGS171 (EM) could ameliorate cognition impairment and showed potential as a useful functional material.
\end{abstract}

Keywords : cholinesterase, cognition, acetylcholine, Alzheimer's disease, dementia

서 론

치매의 주요한 형태인 알츠하이머병(Alzheimer's disease,
$\mathrm{AD})$ 은 주된 증상으로서 점진적인 인지 결손을 가지며(Law 등, 2001), 뇌에서 신경전달물질인 아세틸콜린(acetylcholine, $\mathrm{ACh})$ 생성의 감소, 베타-아밀로이드( $\beta$-amyloide, $\mathrm{A} \beta)$ 의 세포

*Corresponding author. E-mail : herbin3@korea.kr, Phone : +82-43-871-5782, Fax : +82-43-871-5759

Received 18 August 2021; Revised 16 November 2021; Accepted 17 November 2021.

Copyright (c) The Korean Society of Food Preservation.

This is an Open Access article distributed under the terms of the Creative Commons Attribution Non-Commercial License (http://creativecommons.org/licenses/by-nc/4.0) which permits unrestricted non-commercial use, distribution, and reproduction in any medium, provided the original work is properly cited. 
외 축적, 비정상적인 타우 단백질, 산화적 스트레스 및 염증 성 반응 등 여러 가지 인자들이 그 요인으로 제시되었다 (Singhal 등, 2014). ACh는 뇌에서 신경세포 및 시냅스에 신 호를 보내 행동에 영향을 미치는 신경조절자(Picciotto 등, 2012)이다. 한편, $\mathrm{AD}$ 환자의 뇌에서 발견되는 신경전달자의 변화와 관련하여 아세틸콜린에스테라제(acetylcholinesterase, $\mathrm{AChE}$ ), 콜린아세틸트랜스퍼라제(choline acetyltransferse, ChAT) 의 손실이 보고되었다(Talesa, 2001). 인간의 $\mathrm{AChE}$ 를 과도하 게 발현하는 형질전환 마우스에서 점진적인 인지 저하가 보 고되었으며 이것이 $\mathrm{ACh}$ 가 공간 기억에서 역할을 하는 것을 뒷받침하고 있으므로 $\mathrm{AChE}$ 저해물질은 $\mathrm{AD}$ 치료에 이용될 수 있다(Tabet, 2006).

감초는 오랜 기간 사용되어온 한약재로서 그 성분의 하나 인 liquiritin은 우울 유도 랫드에서 만성 스트레스에 대한 항 우울 효과(Zhao 등, 2008), LPS로 자극된 Raw264.7 대식세 포에서 glycyrol의 항염증 효과(Shin 등, 2008), CT 26 tumor 를 가진 생쥐에서 다당류의 면역조절 활성(Ayeka 등, 2017), $\mathrm{Nrf2}$ activator로서 Echinatin 등 성분 구명(Ji 등, 2016) 등 다양한 활성 및 성분연구가 이루어져 있으나 감초 품종에 대 한 효능 연구는 미흡하다. 한편, 본 연구에 사용된 감초 품종 인 원감에 대해서는 in vitro 활성 및 성분에 대하여 감초의 다른 육성품종과 비교한 연구가 Lee 등(2019)에 의해 이루어 졌으며, 기온상승에 따른 생육, 수량, 약리 성분 특성 등에 대 한 연구가 Kim 등(2020)에 의해 이루어져 있을 뿐 인지기능 과 관련하여 깊이 있는 연구는 부족하다.

또한, 수수는 catechin, pyrogallol, chlorogenic acid 등의 페놀성 화합물이 풍부한 주요 식량작물의 하나이다(Seo 등, 2011). 수수의 활성에 관해서는 물 추출물이 대식세포에 의한 사이토카인 생성 증진 및 splenocyte 증식 조절을 통해 면역기 능을 향상(Ryu 등, 2006)시키고, 수수로부터 분리된 peptide 는 herpes simples virus type 1(HSV-1)에 대해 항바이러스 활성(Filho 등, 2008)을 보인다는 보고가 있다. 수수의 겨 (bran) 추출물은 다른 부위에 비해 우수한 항산화 활성을 가 지며(Woo 등, 2010), 수수의 섭취가 트랜스 지방산이나 콜레 스테롤의 흡수를 농도 비례적으로 억제(Kim 등, 2016)하며, 수수의 알코올 가용성 단백질인 kafirin은 사람의 THP-1 대 식세포에서 염증을 저해하는 효과(Sullivan 등, 2018)를 가지 는 것으로 보도되었다.

누에번데기(잠용자, 䖯蛹子)는 동의보감에 누에고체에서 실을 뽑아낸 후 속에 있는 것이며 풍증(風證)과 허로(虛勞)로 여위는 것을 치료한다고 기술되어 있다. 최근 논문에서는 누 에번데기 유래 불포화지방산이 피부건조증 개선 효과(Kang 등, 2006)를 보이며, 누에 번데기 기름은 고지혈증 및 고혈당 증 개선 효과(Mentang 등, 2011)를 나타낸다고 하였다. 또한,
동충하초로 발효된 누에번데기 에탄올 추출물은 항비만 효과 를 보이고, 농축된 누에번데기 오일은 피부주름개선 효과 (Kim 등, 2018; Kwon 등, 2019)를 가진다고 보고되었다. 누 에 나방의 번데기 기름 섭취는 고콜레스테롤 식이를 섭취한 rat에서 산화스트레스를 완화하고 지질 조성을 개선(Zou 등, 2017)하며 누에번데기 분말 섭취와 운동 병행으로 신진대사 기능이 증진될 수 있다고 보고(Son 등, 2018)되었다.

본 연구에서는 선행연구의 in vitro $\mathrm{AChE}$ 저해능 분석을 통 해 선발된 조성물인 BBGS171이 동물모델에서 기억손상 완화 효과를 나타내는지를 검토하고 그 활용성을 평가하고자 하였다.

\section{재료 및 방법}

\section{실험재료}

실험을 위한 시료로 감초 품종인 원감(Wongam, Glycyrriza cultivar)의 뿌리, 수수(Sorgum bicolor (L.) Moench)의 종자 및 누에번데기(pupae of Bombyx mori L., 이하 번데기)를 사 용하였다. 원감 뿌리는 2018년 9월 국립원예특작과학원 약용 작물과로부터 제공받아 상온에서 $50 \%$ 주정으로 추출하였고 수수 종자는 2018년 4월 음성군 농가에서 구입하여 $85^{\circ} \mathrm{C}$ 에 서 $50 \%$ 주정으로 추출하였다. 번데기는 2019년 4월 국립농 업과학원 잠사양봉소재과로부터 제공받아 상온에서 $50 \%$ 주 정으로 추출하였다. 각 시료의 추출은 2 회 반복 및 여과하여 추출액을 합한 후 $50^{\circ} \mathrm{C}$ 의 감압농축기(Eyela N-1200B, Tokyo Rikakikai Co., Ltd, Japan)에서 용매를 제거하였고 남은 수분은 동결건조(PVTFD 50R, ilShinBioBase Co Ltd. Dongducheonsi, Korea)하여 제거하였다. 이렇게 얻어진 번데기 추출물(BB, Beondegi of Bombyx mori L.), 원감 추출물 $(\mathrm{G}$, Glycyrriza cultivar) 및 수수 추출물(S, Sorgum bicolor (L.) Moench)을 1:7:1의 비율로 혼합한 혼합물(BBGS171=EM, extact mixture) 을 제조하여 in vitro 실험에 사용하였다.

In vivo 실험을 위한 시료는 아래와 같이 준비하였다. 추출 물혼합군(EM)은 시판사료(Ziegler Bros Inc., Gardners, PA, $\mathrm{USA}$ )에 혼합추출물 $\mathrm{BBGS171}$ 을 $0.07 \%$ 수준으로 혼합하여 조제하였으며, 추출물원물혼합군(extract and raw material mixture, ENR)은 BBGS171 조성 중 번데기 추출물량에 해당 하는 번데기 원물을 사용하여 원감 추출물, 수수 추출물과 함 께 사료에 혼합하여 조제하였다(Table 1). 실험군은 정상군 (normal), 음성대조군(negative control, $\mathrm{NC}$ ) 추출물혼합군(EM), 추출물원물혼합군(ENR), 및 양성대조군(도네페질, Do)으로 구분하였다 $(\mathrm{n}=10)$.

\section{시약}

실험을 위해 사용된 시약으로 5,5'-dithiobis-(2-nitrobenzoic 
Table 1. Diets for animal study

\begin{tabular}{ccc}
\hline \multirow{2}{*}{ Samples $^{1)}$} & \multicolumn{2}{c}{ Composition $(\mathrm{g})$} \\
\cline { 2 - 3 } & EM diet & ENR diet \\
\hline BB & 0.0467 & Raw material \\
& & 0.5076 \\
$\mathrm{G}$ & 0.3267 & 0.3267 \\
$\mathrm{~S}$ & 0.0467 & 0.0467 \\
Normal diet & 599.5800 & 599.1191 \\
\hline Total & 600.0001 & 600.0001 \\
\hline
\end{tabular}

${ }^{1)} \mathrm{BB}$, Beondegi of Bombyx mori L.; G, glycyrriza cultivar; S, Sorgum bicolor (L.) Moench.

acid (DTNB) solution, acetylthiocholine iodide(또는 butyrylthiocholine iodide, acetylcholinesterase, butyrylcholinesterase, 3-(4,5-dimethylthiazol-2-yl)-2,5-diphenyltetrazolium bromide (MTT), lipopolysaccharide(LPS), dimethyl sulfoxide(DMSO), penicillin \& streptomycin(PEST), sulfanilamide, $N$-1-napthylethylenediamine dihydrochloride(NED), L-glutamate, Trizma base, ethylenediaminetetraacetic acid(EDTA), Donepezil, scopolamine은 Sigma-Aldrich(St. Louis, MO, USA)에서 구 입하였다. Fetal bovine serum(FBS), Dulbecco's minimum essential media(DMEM)는 Thermo Fisher Scientific (Waltham, MA, USA)에서 구매하였고 anti-brain-derived neurotrophic factor(BDNF), anti-extracellular signal-regulated kinase(ERK)1/2은 Abcam(Cambridge, UK)에서 구입하였다. NP-40 및 Bradford protein 시약은 GenDEPOT(Katy, TX, USA)에서, Tris-HCl, dithithreitol, sodium dodecyl sulfate (SDS), bromophenol blue, glycerol은 iNtRON(Seongnam, Korea)에서, polyvinylidene fluoride(PVDF) membrane은 Millipore(Waltham, MA, USA)에서 구입하였으며 anti-mouse IgG, horseradish peroxidase(HRP)-conjugated anti-rabbit은 Cell Signaling(Beverly, MA, USA)에서 구입하였다. 또한, bovine serum albumin(BSA), Tris-buffered saline Tween20(TBST), Tris, NaCl, Tween 20 및 western ECL substrates 는 Bio-Rad(Hercules, CA, USA)에서, choline acetyltransferase (ChAT), acetyl choline 분석을 위한 enzyme-linked immunosorbent assay(ELISA) kits는 Elabscience (Houston, TX, USA) 및 Biovision Inc.(Milpitas, CA, USA)에서 각각 구매 하였다.

\section{세포주 및 배양}

세포 수준에서 BBGS171 추출물의 산화질소 저해능 및 세 포증식율 분석을 위해 mouse brain 유래 microglial cells인
$\mathrm{BV}-2$ 세포주를 사용하였으며 $37^{\circ} \mathrm{C}, 5 \%$ 의 $\mathrm{CO}_{2}$ 조건의 배양 기에서 $5 \% \mathrm{FBS}, 1 \% \mathrm{PEST}$ 를 포함하는 DMEM 배지를 사 용하여 배양하였다.

\section{콜린에스테라제 저해효과 분석}

번데기(BB), 감초 $(\mathrm{G})$ 및 수수(S) 단일 추출물 시료 및 이 들의 추출물 혼합물인 $\mathrm{BBGS171}$ 의 아세틸콜린에스테라제 (AChE), 부티릴콜린에스테라제(BuChE)에 대한 저해효과는 Park 등(2018)의 방법에 준해 실험하였다. Blank(Control) 및 증류수에 녹인 시료 $75 \mu \mathrm{L}$ 를 96 well plate에 각각 넣고, 모든 well에 $100 \mathrm{mM}$ sodium phosphate buffer(pH8.0) $130 \mu \mathrm{L}$ 및 $10 \mathrm{mM}$ DTNB solution 및 $15 \mathrm{mM}$ sodium bicarbonate solution을 1:1 비율로 혼합하여 제조한 Ellman reagent $5 \mu \mathrm{L}$ 를 넣은 후, $75 \mathrm{mM}$ acetylthiocholine iodide(또는 butyrylthiocholine iodide) $1 \mu \mathrm{L}$ 를 넣고 10 분간 차광하여 방치하였 다. $0.5 \mathrm{U} / \mathrm{mL}$ 의 acetylcholinesterase(또는 butyrylcholinesterase) 를 well당 $2.5 \mu \mathrm{L}$ 씩 넣은 후 microplate reader(Bio-Tek, Winooski, VT, USA)를 이용하여 $410 \mathrm{~nm}$ 에서 1시간 동안 30 분 간격으로 흡광도를 측정하였고 결과는 control군 대비 저해율(\%)로 표시하였다.

\section{산화질소(NO) 생성 저해효과 및 세포증식에 대한 영향 분석}

$\mathrm{BV} 2$ 세포 일정량을 48 well plate에 분주한 다음 24 시간 배양한 후 시료를 serum free(SF) media에 녹여 2시간 동안 처리하였다. $11.5 \mu \mathrm{g} / \mathrm{mL} \mathrm{LPS}$ 를 처리하고 24시간 후 각 well 로부터 상등 배지 $50 \mu \mathrm{L}$ 를 취해 96 well plate에 옮겨 담고, $1 \%$ sulfanilamide $50 \mu \mathrm{L}$ 와 $0.1 \% \mathrm{NED} 50 \mu \mathrm{L}$ 를 각각 가하여 혼합한 후 $520 \mathrm{~nm}$ 에서 흡광도를 측정하였다. 세포증식률 분 석을 위해서는 산화질소 저해능 분석실험과 동일한 과정에서 LPS를 처리한 후 24시간째에 각 well로부터 배지를 제거한 후 $0.6 \mathrm{mg} / \mathrm{mL}$ 농도의 MTT 함유한 배지를 처리하였다. 1시 간 후 각 well의 MTT 함유 배지를 제거하고 $\mathrm{DMSO}$ 를 가해 생성된 formazan을 용해한 후 $540 \mathrm{~nm}$ 파장에서 흡광도를 측 정하였다.

\section{동물실험}

앞서 언급한 실험군 구성에 따라 동물실험을 수행하였으 며, 실험동물로는 SD rat 수컷(DBL Co., Eumsung, Korea)을 1 주일간 사육실 환경에 적응시킨 후 14 일간 사료 및 물을 자 유롭게 섭취하게 하였다. 양성대조군에는 도네페질을 $1 \mathrm{mg} / \mathrm{kg}$ 의 용량으로 14 일간 매일 1 회 복강주사하였다. 정상군을 제외 한 각 군에는 스코폴라민 $1 \mathrm{mg} / \mathrm{kg}$ 를 매일 1 회 14 일 동안 복강 주사하여 기억장애를 유발하였고 정상군에는 스코폴라민을 녹인 담체를 복강주사하였다. 동물실험 10 일째에는 Y-maze 
행동시험을 시행하였으며, 변경행동력(\%)은 (실제 변경 / 총 출입횟수 - 2) $\times 100$ 의 식에 따라 산출하였다. 한편, 수동회 피시험(passive avoidance test, PAT)으로는 수동회피시험 장 치를 이용하여 실험 12 일째 및 13 일째에 걸쳐 학습을 시행한 후 14일째에는 최대 300초 동안 밝은 방에서 어두운 방으로 들어가는 시간을 측정하여 회피 정도를 확인하였다. 실험 15 일째에 $\mathrm{CO}_{2}$ 마취하에 동물을 희생하고 채혈한 후 뇌 조직을 적출하였고, 혈액으로부터 분리한 혈청 및 뇌 조직은 $-80^{\circ} \mathrm{C}$ 의 초저온고에 보관하면서 실험에 사용하였다(동물실험승인번 호 NIHHS-2020-002).

\section{뇌 해마 단백질의 western blotting 분석}

뇌 해마 조직에 대해서는 western blotting 기법을 이용하 여 다음과 같이 $\mathrm{BDNF}$ 및 $\mathrm{ERK} 1 / 2$ 발현을 분석하였다. 조직 mg/10 $\mu$ L에 1X NP-40 lysis buffer $(100$ mM Tris-HCl, 300 $\mathrm{mM} \mathrm{NaCl}, 10 \mathrm{mM} \mathrm{EDTA}, 2 \% \mathrm{NP}-40$ )를 첨가하여 원심관 샘 플 패슬(SL.Tub3101.1, SPL)을 이용하여 조직을 균질화시키 고 원심분리 $\left(4^{\circ} \mathrm{C}, 12,000 \mathrm{rpm}, 25\right.$ 분 $)$ 한 후 상등액을 사용하였 다. Bradford Protein 분석시약을 사용하여 $595 \mathrm{~nm}$ 에서 흡광 도를 측정하여 단백질을 정량하였다. 정량한 단백질 $(15 \mu \mathrm{g})$ 은 5X loading buffer(250 mM Tris-HCl, pH6.8, 0.5 M dithithreitol, $10 \%$ SDS, $0.1 \%$ bromophenol blue, $50 \%$ glycerol)과 증류수를 섞어 $95^{\circ} \mathrm{C}$ 에서 5 분 동안 가열하였다. 동일 한 양의 단백질을 $12 \%$ SDS-polyacrylamide gel electrophoresis (PAGE) gel로 크기에 따라 단백질을 분리한 후 Wet/Tank Blotting System(Tanon)을 이용하여 PVDF membrane (Millipore)에 transfer하였다. Membrane은 5\% BSA/TBST에 넣고 1시간 blocking한 후 primary antibody[anti-BDNF (1:1000 dilution) 또는 anti-ERK1/2(1:1000 dilution)]를 $4^{\circ} \mathrm{C}$ 에서 overnight 반응하였다. TBST로 3 회 세척 후 2차 항체 antimouse IgG 또는 HRP-conjugated anti-rabbit(1:2000 dilution) 으로 실온에서 1 시간 반응시켰다. TBST로 3 회 세척 후 western ECL substrates를 처리하고 ChemiDoc ${ }^{\mathrm{TM}}$ Imaging Systems(BioRad, Hercules, CA, USA)을 이용하여 단백질 발현을 확인하 였다.

\section{뇌 해마의 ChAT 및 혈청의 acetylcholine 분석}

확보한 뇌 조직은 ELISA kit를 이용하여 콜린아세틸트랜 스퍼라제(ChAT)를 분석하였고 혈청 중의 아세틸콜린(Ach) 함 량 분석도 ELISA kit를 사용하여 진행하였다.

\section{통계분석}

결과는 반복 실험으로 얻은 in vitro 실험결과 $(\mathrm{n}=3)$ 및 in vivo 실험결과 $(\mathrm{n}=8-10)$ 를 평균 \pm 표준편차로 나타내었으며, 통
계적 유의성은 SAS program(version 9.4, SAS Institute Inc., Cary, NC, USA)에서 ANOVA 분석을 실시하여 유의성이 있 을 경우 $\mathrm{p}<0.05$ 수준에서 Duncan's Multiple Range Test (DMRT)를 실시하였다.

\section{결과 및 고찰}

\section{BBGS171의 콜린에스테라제 저해능에 대한 영향}

해마의 $\mathrm{AChE}$ 활성은 $\mathrm{AD}$ 초기와 가벼운 인지 손상에서만 감소하므로 $\mathrm{AChE}$ 저해제는 경증부터 중등 정도의 $\mathrm{AD}$ 치료 에 사용(Galimberti와 Scarpini, 2016)될 수 있어 원감, 수수 및 번데기 추출혼합물인 $\mathrm{BBGS171}$ 을 재료로 하여 $\mathrm{AChE}$ 및 $\mathrm{BuChE}$ 에 대한 저해 정도를 분석하였다. 그 결과, $100 \mu \mathrm{g} / \mathrm{mL}$ 농도로 처리하였을 때 $\mathrm{AChE}$ 저해능에서는 $22.7 \%$ 의 효과를 나타내었으므로 단일시료들의 $0.4 \%-13.8 \%$ 에 비해 유의하게 우수하였다(Fig. 1(A)). BuChE에 대한 저해 효과에서는 100 $\mu \mathrm{g} / \mathrm{mL}$ 농도에서 단일시료들은 $-13.1 \%-3.5 \%$ 의 값을 보인 데 비해 BBGS171은 5.8\%의 저해효과를 보여 비교적 우수한 것으로 확인되었다(Fig. 1(B)). 한편, 모든 시료들의 $\mathrm{AChE}$ 저해능은 $\mathrm{BuChE}$ 에 대한 저해능에 비해 높았다. 한편, Park 등(2018)은 180 여 개의 식물 추출물의 $\mathrm{AChE}$ 저해활성을 $100 \mu \mathrm{g} / \mathrm{mL}$ 처리농도에서 분석하여 보고하였으며, 이러한 결 과를 본 실험에서의 시료인 $\mathrm{BBGS} 171$ 의 $\mathrm{AChE}$ 저해능(22.7\%) 과 비교하였을 때, 이와 비슷하거나 더 우수한 시료는 6개 정 도 확인되었으므로 $\mathrm{BBGS171}$ 은 상당히 우수한 $\mathrm{AChE}$ 저해 효과를 나타내는 소재인 것으로 사료되었다.

\section{BBGS171의 NO 생성 저해효과 및 세포증식에 대한 영향}

염증은 노인에 있어 치매와 인지 감소의 기초가 되는 중요 한 기전이며 알츠하이머병과 인생 후반기의 다른 일반적인 형태의 치매로의 진행에 관여하는 신경병리학적 과정과 연관 되어 있다(Gorelick, 2010). Microglia(소교세포)는 뇌 조직의 대식세포이자 $\mathrm{AD}$ 의 염증 과정에 관련되어 있어 뇌 기능에서 여러 가지 중요한 역할을 가지는 인자의 하나이다. 신경퇴행 성 질환에서 염증 반응은 신경퇴화에 영향을 주고, 소교세포 의 조절 이상과 과활성화의 결과로서 염증이 매개한 신경독 성이 유발된다(Block 등 2007; McGeer 등 1988). 본 연구에 서는 생쥐의 소교세포인 BV2 세포에 LPS를 처리하였을 때 생성되는 산화질소에 대해 BBGS171 처리가 나타내는 저해 효과 및 세포증식에 대한 영향을 분석하였다. 그 결과, $\mathrm{NO}$ 생성에 대해서는 $6.25-25 \mu \mathrm{g} / \mathrm{mL}$ 농도의 BBGS171로 42.1$48.7 \%$ 의 억제 효과를 각각 나타내었다(Fig. 2(A)). 이처럼 본 실험에서의 $\mathrm{BBGS} 171$ 처리가 $\mathrm{NO}$ 생성을 감소시킨 것은 $\mathrm{BV} 2$ 세포에 LPS를 처리로 대조군에 비해 증가한 $\mathrm{NO}$ 생성 
(A)

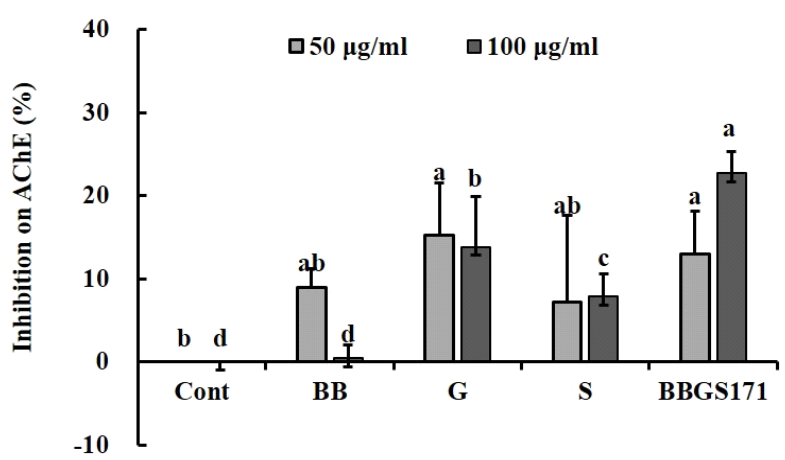

(B)

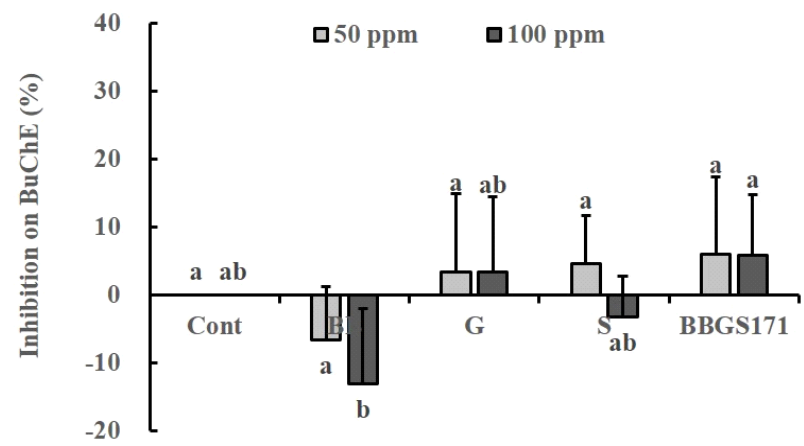

Fig. 1. Effect of BBGS171 on (A) acetylcholinesterase (AChE) and (B) butyrylcholinesterase (BuChE) activities.

Samples (final concentrations of 50 and $100 \mu \mathrm{g} / \mathrm{mL}$ ) were reacted into a 96-well plate of $100 \mathrm{mM}$ sodium phosphate buffer (pH 8.0 ), $10 \mathrm{mM}$ DTNB reagent, $75 \mathrm{mM}$ acetylthiocholine iodide (or butyrylthiocholine iodide) and AChE (or BuChE) enzyme. Absorbances of the reactants were measured at $410 \mathrm{~nm}$. Means $\pm \mathrm{SD}$ from triple test data is presented $(\mathrm{n}=3)$. (Cont, control; BB, Bombyx mori L.; G, Glycyrrhiza cultivar (Wongam); S, Sorghum bicolor (L.) Moench, BBGS171, mixed extract of BB, G and S). Statistical analysis was performed by using SAS program. Values with different alphabet are significantly different at $\mathrm{p}<0.05$ by Duncan's multiple range test (DMRT).

(A)

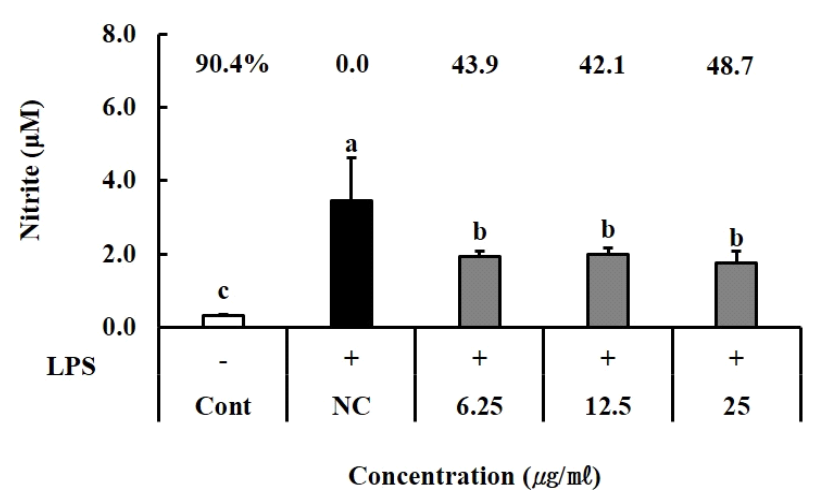

(B)

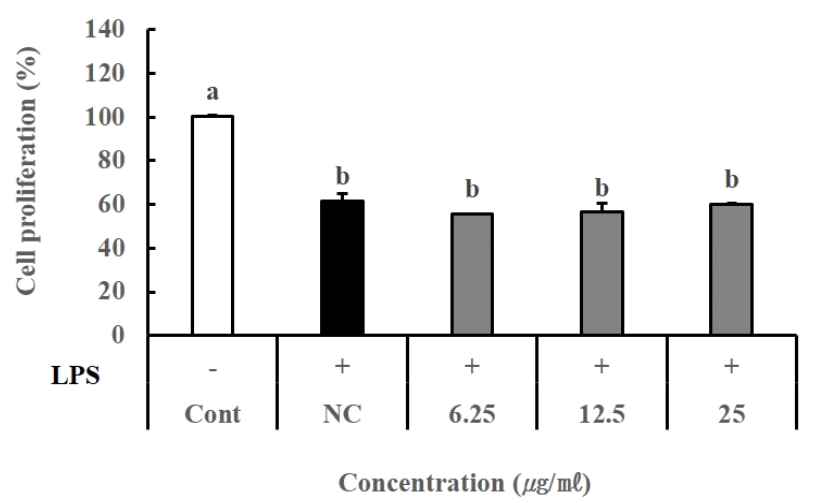

Fig. 2. Effect of BBGS171 on (A) nitric oxide (NO) production and (B) cell proliferation.

BV-2 cells $\left(1 \times 10^{5}\right.$ cells/well $)$ in 48 -well plate were treated with sample extracts in serum free (SF) media for 2 hours and with dimethyl sulfoxide (DMSO) in SF media as normal and negative control. The wells were treated with $11.5 \mu \mathrm{g} / \mathrm{mL}$ LPS for $24 \mathrm{~h}$. Optical densities of the reaction supernatant were measured at $520 \mathrm{~nm}$. (-), LPS-untreated experiment; (+), LPS-treated experiment. Nor, normal; NC, negative control. Statistical analysis was performed by using SAS program. Values with different alphabet are significantly different at $\mathrm{p}<0.05$ by Duncan's multiple range test (DMRT).

이 생강의 헥산 분획물 $(1 \mu \mathrm{g} / \mathrm{mL}$ 및 $10 \mu \mathrm{g} / \mathrm{mL})$ 처리 시 감소 되었다고 보고한 Jung 등(2009)의 결과와 일치되는 경향이었 으므로 BBGS171가 염증에 대해 억제 효과를 가질 것으로 예상되었다. 한편, 세포증식에 대한 영향 분석 실험에서는 $\mathrm{BBGS} 171$ 가 LPS 처리로 $61.5 \%$ 로 감소된 세포증식율과 같 은 수준인 55.7-60.0\%의 수치를 나타내 세포에 대해 증식 효 과를 보이지는 않았다(Fig. 2(B)).

\section{BBGS171의 동물행동에 대한 영향}

Y-maze 시험의 자발적인 변경행동력 측정과 수동회피시
험은 각각 단기적 혹은 장기적 공간 기억력을 반영하는 기억 수행 측정(Senechal 등, 2008)을 위해 수행하였다.

실험결과, Y-maze 시험에서 변경행동력은 정상군 $100 \%$ 에 비해 음성대조군에서 $87.0 \%$ 로 감소하였고, 추출혼합물(EM) 투여군 및 추출물원물의 혼합물(ENR) 투여군이 각각 $96.1 \%$ 및 $96.0 \%$ 로 증가함을 확인하였으며, 이는 도네페질 처리군의 $88.5 \%$ 와 같은 수준이었다(Fig. 3(A)). 이는 스코폴라민 투여 로 기억장애를 유발한 마우스에 대해 Y-maze 시험을 시행하 면 스코폴라민을 투여하지 않은 정상 마우스에 비해 변경행 동력이 감소하였지만 $\mathrm{ChAT}$ 를 활성화시키는 물질을 처리함 
(A)

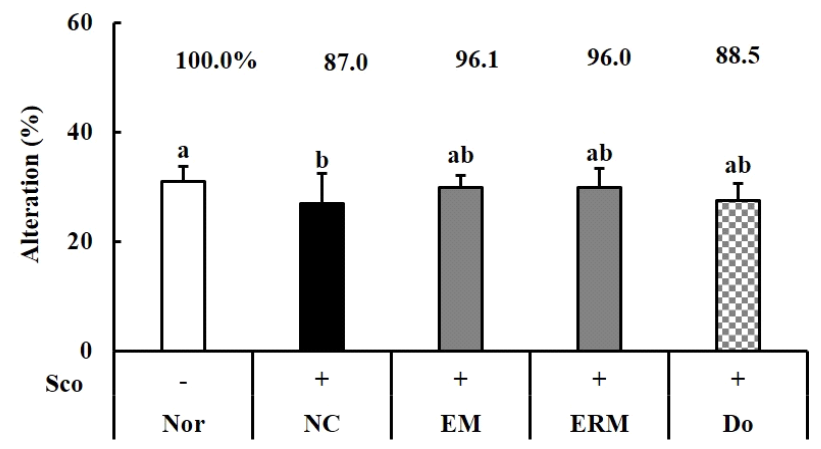

(B)

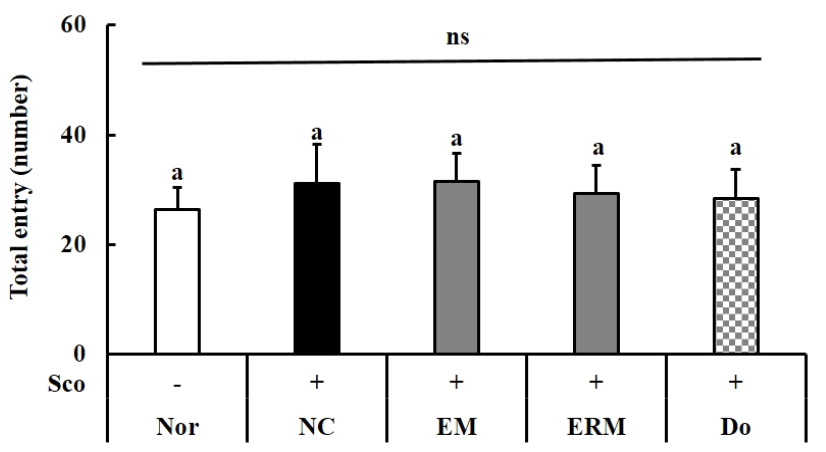

Fig. 3. Effect of EM (BBGS171) and ENR prepared from Glycyrrhiza cultivar (Wongam) and Sorghum bicolor (L.) Moench and Bombyx mori L. on (A) spontaneous alteration and (B) total entry level of Y-maze test in rats treated with scopolamine.

Rats were randomly divided into five groups. Nor, normal diet; NC, negative control, normal diet+scopolamine; EM, extract mixture diet of BBGS171+scopolamine; ENR, extract and raw material mixture diet+scopolamine; Do, normal diet + donepezil $(1 \mathrm{mg} / \mathrm{kg})+\mathrm{scopolamine}(\mathrm{n}=10)$. All of the rats except normal rats was intraperitoneally injected with scopolamine $(1 \mathrm{mg} / \mathrm{kg}$ in $0.9 \%$ saline $)$ one time per day for 14 days. Diets and water were free to access. Statistical analysis was performed by using SAS program. Values with different alphabet are significantly different at $\mathrm{p}<0.05$ by Duncan's multiple range test (DMRT).

으로써 그 수준이 증가하였다고 보고한 Heo 등(2003)의 결 과와 일치하는 것으로서 EM 및 ENR 섭취가 rat의 변경행동 력을 증가시켰음을 나타내는 결과로 사료되었다. 반면, 모든 실험군의 총 출입 횟수는 유의한 차이를 보이지 않았다(Fig. 3(B)).

또한, 수동회피시험에서는 밝은 방에서 어두운 방으로 실 험동물이 들어가는 데 걸리는 회피시간을 측정하였으며, 그 결과 정상군에 비해 음성대조군에서 회피시간이 감소하였으 나 원감 추출물, 수수 추출물 및 번데기 추출물의 혼합물인 $\mathrm{EM}$ 을 포함하는 사료를 투여한 실험군에서는 증가하는 것을 확인하였으므로 $\mathrm{EM}$ 혼합물이 스코폴라민 투여로 감소된 회 피시간을 증가시킴으로서 기억력개선 효과를 보이는 것을 알 수 있었다. 이러한 결과는 복분자 물 추출물을 4주간 투여한 후 스코폴라민(1 mg/kg body weight)을 투여하였을 때, 스코 폴라민만을 투여한 대조군에 비해 체류시간이 현저히 증가하 였다고 보고한 Choi 등(2012)의 결과와도 일치하는 것이었다. 반면 원감의 추출물, 수수의 추출물 및 번데기 원료의 혼합물 인 ENR을 포함한 사료를 투여한 실험군과 양성대조물질인 도네페질 $(\mathrm{Do})$ 을 투여한 실험군은 음성대조군과 같은 정도의 회피시간을 나타내었다(Fig. 4). 따라서, 음성대조군에 비해 수동회피시험에서 회피시간이 증가되었던 원감, 수수, 번데기 의 추출혼합물 $\mathrm{EM}$ 이 ENR보다 스코폴라민에 의한 기억력 손 상을 효과적으로 완화시키는 것으로 사료되었다.

\section{BBGS171의 ChAT 및 acetylcholine 수준에 미치는 영향}

아세틸콜린(ACh)은 모든 콜린성 신경에 의해 사용되는 신 경전달물질로서 말초신경과 중추신경계에서 중요한 역할을

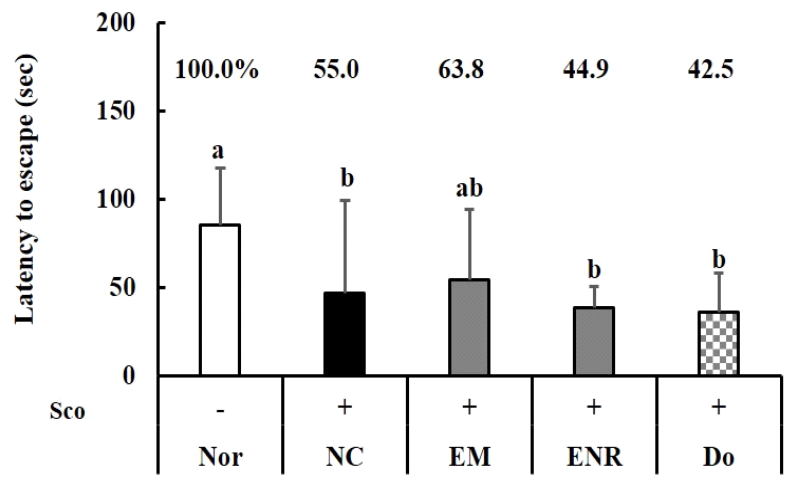

Fig. 4. Effect of EM (BBGS171) and ENR prepared from Glycyrrhiza cultivar (Wongam) and Sorghum bicolor (L.) Moench and Bombyx mori $\mathrm{L}$. on escape latency of rats treated with scopolamine in passive avoidance test.

Rats were randomly divided into five groups. Nor, normal diet; NC, negative control, normal diet+scopolamine; EM, extract mixture diet of BBGS171+scopolamine; ENR, extract and raw material mixture diet + scopolamine; Do, normal diet + donepezil $(1 \mathrm{mg} / \mathrm{kg})+$ scopolamine $(\mathrm{n}=10)$. All of the rats except normal rats was intraperitoneally injected with scopolamine $(1 \mathrm{mg} / \mathrm{kg}$ in $0.9 \%$ saline $)$ one time per day for 14 days. Diets and water were free to access. Statistical analysis was performed by using SAS program. Values with different alphabet are significantly different at $p<0.05$ by Duncan's multiple range test (DMRT).

하는데 시냅스 간극 중에서 $\mathrm{AChE}$ 에 의해 분해되며, 콜린 아 세틸트랜스퍼라제 $(\mathrm{ChAT})$ 는 신경전달물질인 아세틸콜린을 합성하는 효소로서 콜린성 신경세포의 기능적 상태를 관찰할 수 있는 인자이다(Ferreira-Vieira 등, 2016; Lim 등, 2016). $\mathrm{AD}$ 에서 대뇌 피질과 해마의 콜린아세틸트랜스퍼라제의 활 성 소실은 치매 정도와 기간과 관련되므로 치료의 기초가 되 
는데, 전뇌 피질과 해마의 $\mathrm{ChAT}$ 활성을 높이는 것은 경도인 지장애인이 $\mathrm{AD}$ 로 전이되는 것을 막는 주요한 인자이다 (DeKosky 등, 2002). 본 연구에서 스코폴라민으로 기억장애 를 유발한 흰쥐의 뇌 해마에서 ChAT 수준에 대한 분석 결과, 정상군 $(100 \%)$ 에 대비하여 음성대조군에서 $42.4 \%$ 로 감소하 였으나 원감, 수수 및 번데기 추출혼합물인 $\mathrm{EM}$ 을 투여한 실 험군에서는 $110.5 \%$ 로 증가하였다. 하지만 원감, 수수의 추출 물 및 번데기 원물의 혼합물인 ENR을 투여한 실험군에서는 ChAT 함량은 증가를 확인할 수 없었다(Fig. 5(A)). 이처럼 $\mathrm{EM}$ 이 ChAT 수준을 증가시킨 결과는 기억개선 물질을 투여 한 실험군이 스코폴라민으로 기억장애를 유발한 대조군에 비 해 ChAT 발현이 유도되어 실험동물의 기억장애를 개선한다 고 보고한 결과들( $\operatorname{Lim}$ 등, 2016; Oh 등, 2009)과 일치하는 경향이었으며, ENR보다는 EM이 스코폴라민 투여로 감소한 $\mathrm{ChAT}$ 함량을 개선시킴으로서 기억장애의 완화 작용이 우수 한 것으로 사료되었다.

신경전달물질인 아세틸콜린(ACh)의 혈청 중에서의 함량을 분석한 결과, 정상군 $(100 \%)$ 에 비해 음성대조군에서는 $96.9 \%$ 로 다소 감소하였으나 $\mathrm{EM}$ 을 투여한 실험군에서는 $98.6 \%$ 로 증가하였고, ENR을 투여한 실험군에서는 $92.3 \%$ 로 감소하였 다. 이러한 결과로부터 ENR 투여보다는 EM을 투여하였을 때보다 효과적으로 아세틸콜린 함량 증가가 됨을 알 수 있었 다(Fig. 5(B)). 한편, Giridharan 등(2011)은 스코폴라민이 뇌 균질액에서 $\mathrm{ACh}$ 수준 감소를 유도하였고, 반면에 $\mathrm{MEC}$ (methanolic extract of chaga)는 그 감소를 막아주었으며 정 상 수준으로 유지시켰다고 보고하였다. 이러한 결과는 본 연 구 결과에서 ENR 투여보다는 EM 투여에 의해 혈청 중에서
의 $\mathrm{ACh}$ 수준이 유의하게 증가하였을 뿐만 아니라 정상군과 통계학적으로 같은 수준을 나타낸 것과 일치하는 결과였으며 이는 $\mathrm{EM}$ 이 기억력 개선에 도움을 줄 수 있음을 시사한다.

\section{BBGS171가 해마의 BDNF 발현 및 ERK1/2 발현에 미치는 영향}

뇌 유래신경영양인자인 BDNF는 대뇌피질과 해마에 존재 하는 신경계의 성장인자로서 비강내피질로부터 해마로 전달 되고 기억과 관련된다(Lee 등, 2018). 알츠하이머 환자군은 정상군에 비해 해마와 주변 대뇌피질에서의 $\mathrm{BDNF}$ 수준이 감소되었으며 스코폴라민 투여 실험동물에서는 해마의 BDNF 발현이 정상군에 비해 감소되었으나 기억개선소재를 투여한 실험군에서는 회복되었다(Hock 등, 2000; Lv 등, 2020). 본 연구에서는 원감 추출물, 수수 추출물 및 번데기 추출물로 조 성된 혼합물인 EM 및 원감 추출물, 수수 추출물 및 번데기 원물로 구성된 혼합물인 $\mathrm{ENR}$ 을 기억장애 유발된 흰쥐에 투 여하였을 때, 흰쥐 뇌 해마에서의 $\mathrm{BDNF}$ 단백질 발현이 정상 군(100\%)에 비해 음성대조군에서 $73.0 \%$ 로 감소하였으나 추 출혼합물 $\mathrm{EM}$ 을 투여한 군에서는 $91.3 \%$ 로 증가하였고 이는 양성대조물질인 도네페질 투여군(90.4\%)보다 높은 수치였기 에 $\mathrm{EM}$ 투여는 기억장애 완화에 기여할 것으로 사료되었다. 하지만 원감 추출물, 수수 추출물 및 번데기 원물로 구성된 혼합물인 ENR을 포함한 사료를 투여한 실험군에서는 음성 대조군과 같은 정도로 $\mathrm{BDNF}$ 단백질 발현이 나타났으므로 기억장애 완화에 큰 도움을 주지 못할 것으로 사료되었다 (Fig. 6(A)).

또한, ERK1/2은 신경계에서 기억형성뿐만 아니라 시냅스
(A)

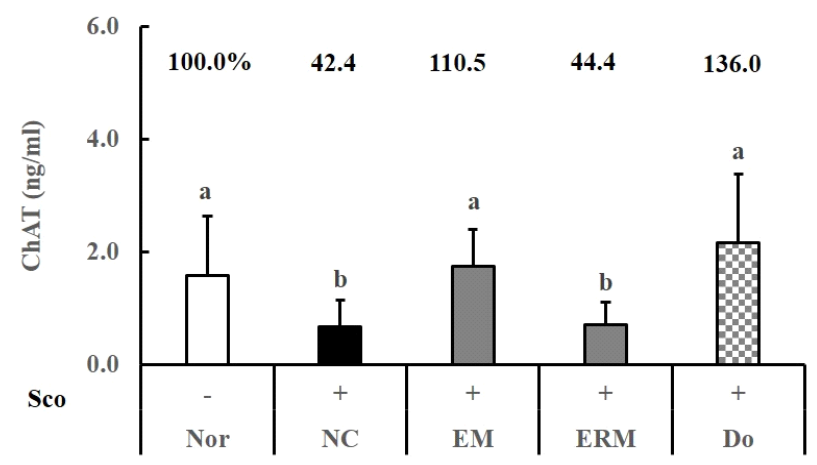

(B)

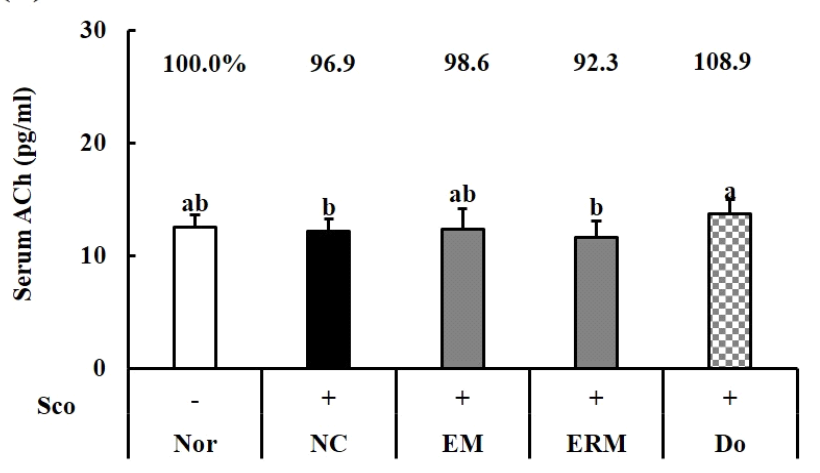

Fig. 5. Effect of EM (BBGS171) and ENR prepared from Glycyrrhiza cultivar (Wongam) and Sorghum bicolor (L.) Moench and Bombyx mori L. on (A) hippocampal choline acetyltransferase (ChAT) activity and (B) serum acethylcholine level in rats treated with scopolamine.

Rats were randomly divided into five groups. Nor, normal diet; NC, negative control, normal diet+scopolamine; EM, extract mixture diet of BBGS171+scopolamine; ENR, extract and raw material mixture diet+scopolamine; Do, normal diet+donepezil $(1 \mathrm{mg} / \mathrm{kg})+\mathrm{scopolamine}(\mathrm{n}=10)$. All of the rats except normal rats was intraperitoneally injected with scopolamine $(1 \mathrm{mg} / \mathrm{kg}$ in $0.9 \%$ saline $)$ one time per day for 14 days. Diets and water were free to access. Statistical analysis was performed by using SAS program. Values with different alphabet are significantly different at $\mathrm{p}<0.05$ by Duncan's multiple range test (DMRT). 
(A)

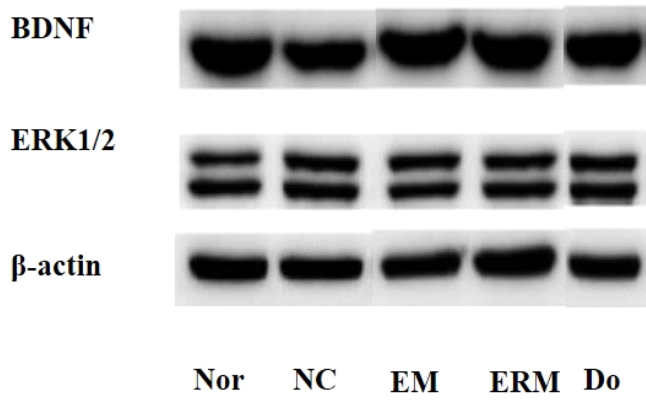

(B)

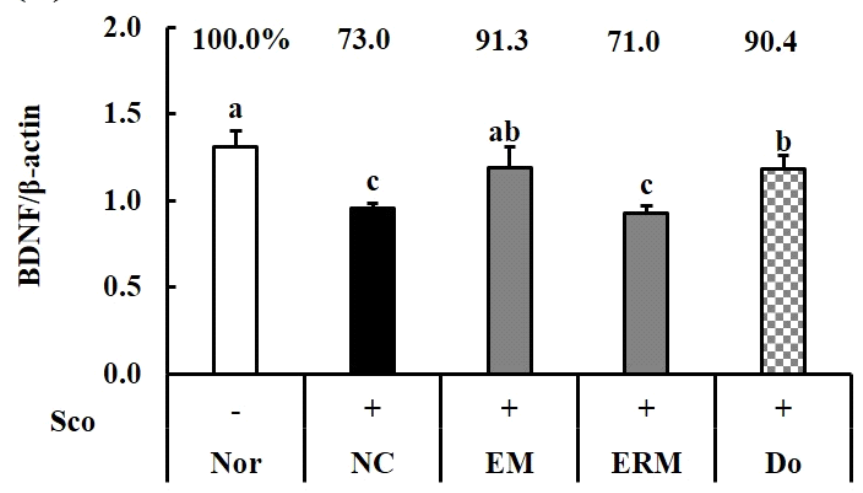

(C)

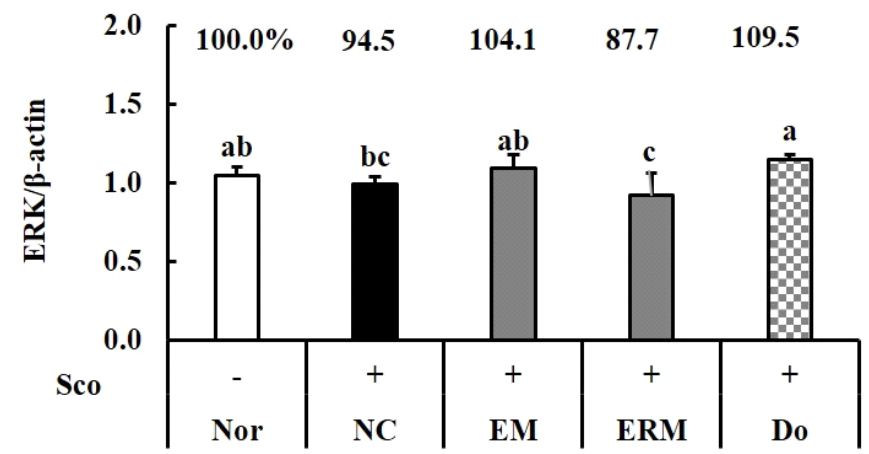

Fig. 6. Effect of EM (BBGS171) and ENR prepared from Glycyrrhiza cultivar (Wongam) and Sorghum bicolor (L.) Moench and Bombyx mori L. on (A) protein expression, (B) density of BDNF level and (C) density of ERK in rat hippocampus treated with scopolamine.

Rats were randomly divided into five groups. Nor, normal diet; NC, negative control, normal diet+scopolamine; EM, extract mixture diet of BBGS171+scopolamine; ENR, extract and raw material mixture diet + scopolamine; Do, normal diet + donepezil $(1 \mathrm{mg} / \mathrm{kg})+\mathrm{scopolamine}(\mathrm{n}=10)$. All of the rats except normal rats was intraperitoneally injected with scopolamine (1 mg/kg in $0.9 \%$ saline $)$ one time per day for 14 days. Diets and water were free to access. Statistical analysis was performed by using SAS program. Values with different alphabet are significantly different at $\mathrm{p}<0.05$ by Duncan's multiple range test (DMRT).

가소성, 뇌 발달, 수선 등을 조절하며 많은 중추신경계 질환 에 있어서 신경세포사 및 신경염증에 대한 유력한 영향 인자 로서 ERK1/2 활성의 증가는 정서, 각성뿐만 아니라 기억형 성과 학습을 위해 필요하다(Sun과 Nan, 2017). 본 실험결과 에서는 ERK1/2 단백질 발현에 있어서 정상군(100\%)에 비해 음성대조군(94.\%)에서 감소하였으며, 추출혼합물 $\mathrm{EM}$ 포함 사료를 투여한 실험군(104.1\%)에서는 증가하였으나 ENR 포 함 사료를 투여한 실험군(87.7\%)에서는 감소하는 것을 알 수 있었다(Fig. 6(B)). Hafez 등(2017)은 스코폴라민 투여로 기 억장애를 유발한 실험동물의 해마에서 ERK1/2 단백질 분석 을 하였을 때, 정상군에 비해 감소한 $\mathrm{ERK} 1 / 2$ 단백질이 $\mathrm{AChE}$ 저해물질(또는 도네페질)의 투여로 증가하였다고 보 고하였다. 이러한 보고를 본 연구의 결과와 비교하였을 때, 추출혼합물인 $\mathrm{EM}$ 의 투여는 음성대조군에서와 같이 스코폴 라민 투여로 감소한 ERK1/2 발현을 개선시킨 것으로 사료되
며, EM의 투여가 ENR의 투여보다 기억, 학습 등에 필요한 $\mathrm{ERK} 1 / 2$ 활성의 증가에 더 효과적으로 작용하는 결과로 사료 되었다.

이처럼 원감 추출물, 수수 추출물 및 번데기 추출물로 조 성된 혼합물인 $\mathrm{EM}$ 이 원감 추출물, 수수 추출물 및 번데기 원물로 구성된 혼합물인 ENR보다 기억력 관련 지표들에서 비교적 우수한 효과를 나타낸 것은 $\mathrm{EM}$ 의 구성 물질인 원감 추출물, 수수 추출물 및 누에의 번데기 추출물이 원물이 일부 혼합된 ENR보다 우수한 시너지 효과를 나타낸 데 따른 것으 로 사료된다(Kim 등, 2015; Park 등, 2013).

\section{요 약}

알츠하이머 치매를 포함하는 치매는 신경퇴화를 보이며 주요 증상으로 점진적인 인지기능결손을 보이는 심각한 질환 
이다. 감초 품종의 하나인 원감의 뿌리 추출물, 수수의 종자 추출물 및 누에번데기 추출물로 조성된 혼합물인 BBGS171 (EM)은 인지기능개선 활성과 관련한 in vitro 예비실험을 통 해 선발되었다. $\mathrm{BBGS171}$ 는 in vitro 조건에서 $\mathrm{AChE}$ 및 $\mathrm{BuChE}$ 등의 cholinesterase들에 대해 저해활성을 보였으며 LPS가 처리된 BV2 세포에서 산화질소(NO) 생성을 저해하였 다. In vivo 실험에서는 스코폴라민으로 인지장애를 유발하면 서 BBGS171 (EM)이 포함된 사료를 섭취한 rat가 스코폴라 민만을 투여한 대조군의 랫드에 비해 Y-maze에서의 자발적 행동변경력과 수동회피시험에서의 도피경향을 개선하였다. 또한, 뇌 해마의 콜린 아세틸트랜스퍼라제(ChAT) 수준 및 혈청의 아세틸콜린(ACh) 수준은 $\mathrm{EM}$ 포함 사료를 섭취한 실 험군에서 대조군보다 높았고, 대조군에서 낮아진 뇌 해마에 서의 $\mathrm{BDNF}$ 발현 및 $\mathrm{ERK} 1 / 2$ 발현을 $\mathrm{EM}$ 사료 섭취군이 개 선시켰다. 이러한 결과를 종합할 때, 원감 추출물, 수수 추출 물 및 누에번데기 추출물로 조성된 혼합물인 $\mathrm{EM}(\mathrm{BBGS171)}$ 은 인지기능장애를 완화할 수 있는 기능성 소재로 이용이 가 능할 것으로 사료되었다.

\section{감사의 글}

본 연구는 농촌진흥청 시험연구사업(PJ01356503)의 연구 비 지원으로 수행된 결과이며 이에 깊은 감사를 드립니다.

\section{Conflict of interests}

The authors declare no potential conflict of interest.

\section{ORCID}

Seung-Eun Lee https://orcid.org/0000-0003-1511-3262

\section{References}

Ayeka PA, Bian Y, Githaiga PM, Zhao Y. The immunomodulatory activities of licorice polysaccharides (Glycyrrhiza uralensis Fisch.) in CT 26 tumor-bearing mice. BMC Complem Altern M, 17, 536 (2017)

Block ML, Zecca L, Hong JS. Microglia-mediated neurotoxicity: Uncovering the molecular mechanisms. Nat Rev Neurosci, 8, 57-69 (2007)

Choi MR, Lee MY, Hong JE, Lee JY, Chun JW, Kim TH, Shin HK, Kim EJ. The aqueous extract of Rubus coreanus Miquel improves scopolamine-induced memory impairment in ICR mice. J Korean Soc Food Sci Nutr 41, 192-196 (2012)

DeKosky ST, Ikonomovic MD, Styren SD, Beckett L, Wisniewski S, Bennett DA, Cochran EJ, Kordower JH, Mufson EJ. Upregulation of choline acetyltransferase activity in hippocampus and frontal cortex of elderly subjects with mild cognitive impairment. Ann Neurol, 51, 145-155 (2002)

Ferreira-Vieira TH, Guimaraes IM, Silva FR, Ribeiro FM. Alzheimer's disease: Targeting the cholinergic system. Curr Neuropharmacol, 14, 101-115 (2016)

Filho IC, Cortez DAG, Nakamura TU, Nakamura CV, Filho BPD. Antiviral activity and mode of action of a peptide isolated from Sorghum bicolor. Phytomedicine, 15, 202208 (2008)

Galimbert D, Scarpini E. Old and new acetylcholinesterase inhibitors for Alzheimer's disease. Expert Opin Inv Drug, 25, 1181-1187 (2016)

Giridharan VV, Thandavarayan RA, Konishi T. Amelioration of scopolamine induced cognitive dysfunction and oxidative stress by Inonotus obliquus: A medicinal mushroom. Food Funct, 2, 320-327 (2011)

Gorelick PB. Role of inflammation in cognitive impairment: Results of observational epidemiological studies and clinical trials. Ann N Y Acad Sci, 1207, 155-162 (2010)

Hafez HS, Ghareeb DA, Saleh SR, Abady MM, Demellawy MAE, Hend Hussien H, Nihad Abdel-Monem N. Neuroprotective effect of ipriflavone against scopolamineinduced memory impairment in rats. Psychopharmacology, 234, 3037-3053 (2017)

Heo HJ, Park YJ, Suh YM, Choi SJ, Kim MJ, Cho HY, Chang YJ, Hang B, Kim HK, Kim E, Kim CJ, Kim BG, Shin DH. Effects of oleamide on choline acetyltransferase and cognitive activities. Biosci Biotechnol Biochem, 67, 1284-1291 (2003)

Hock C, Heese K, Hulette C, Rosenberg C, Otten U. Region-specific neurotrophin imbalances in Alzheimer disease: Decreased levels of brain-derived neurotrophic factor and increased levels of nerve growth factor in hippocampus and cortical areas. Arch Neurol, 57, 846851 (2000)

Ji S, Li Z, Song W, Wang Y, Liang W, Li K, Tang S, Wang Q, Qiao X, Zhou D, Yu S, Ye M. Bioactive constituents of Glycyrrhiza uralensis (Licorice): Discovery of the 
effective components of a traditional herbal medicine. J Nat Prod, 79, 281-292 (2016)

Jung HY, Joo YJ, Jung HM, Shin WJ, Seo UK. Hexane fraction of Zingiberis rhizoma crudus extract inhibits the production of nitric oxide and pro-inflammatory cytokines in LPS-stimulated BV2 microglial cells. J Korean Oriental Med, 30, 17-29 (2009)

Kang PD, Kim JW, Jung IY, Kim KY, Kang SW, Kim MJ, Ryu KS. Study on the unsaturated fatty acids in the pupae of silkworm, Bombyx mori. Korean J Seric Sci, 48, 21-24 (2006)

Kim J, Noh SK, Woo KS, Seo MC. Sorghum extract lowers lymphatic absorption of trans fat and cholesterol in rats. J Korean Soc Food Sci Nutr, 45, 783-788 (2016)

Kim JE, Lee MR, Choi JY, Park JJ, Kim HR, Song BR, Choi YW, Kim KM, Hwang DY. Anti-obesity effect of ethanol extracts from silkworm (Bombyx mori) pupae powder fermented with Cordyceps militaris in the primary adipocytes and high fat diet-induced obesity model mice. J Life Sci, 28, 786-794 (2018)

Kim JH, Cho YK, Kim BK, Kwack SJ, Kim JG, Lee E, Cho HK, Kim KJ. The effect of Coptidis rhizoma, Chinese galls and phytoncide in Malassezia furfur. J Life Sci, 25, 748-756 (2015)

Kim YI, Lee JH, An TJ, Lee ES, Park WT, Kim YG, Chang JK. Study on the characteristics of growth, yield, and pharmacological composition of a new Glycyrrhiza variety licorice 'Wongam (Glycyrrhiza glabra × Glycyrrhiza uralensis)' in temperature gradient tunnel and suitable cultivation area of Korean. Korean J Hortic Sci Technol, 38, 44-55 (2020)

Kwon MG, Park SH, Kim MS. Wrinkle improvement of functional cosmetics using concentrated oil of silkworm chrysalis. J Korean Soc Cosmetol, 25, 1264-1270 (2019)

Law A, Gauthier S, Quirion R. Say no to Alzheimer's disease: The putative links between nitric oxide and dementia of the Alzheimer's type. Brain Res Rev, 35, 73-96 (2001)

Lee JE, Song H, Park MN, Kim SH, Shim BS, Kim B. Ethanol extract of Oldenlandia diffusa herba attenuates scopolamine-induced cognitive impairments in mice via activation of BDNF, P-CREB and inhibition of acetylcholinesterase. Int J Mol Sci, 19, 363 (2018)

Lee SE, Lee JH, Park CG, Kim HD, Lee YJ, Seo KH, Jeong
HS, Chang JK, Kim DH. Evaluation of the in vitro activity of Glycyrrhiza cultivar roots. Korean J Medicinal Crop Sci, 27, 115-125 (2019)

Lim DW, Son HJ, Um MY, In-Ho Kim IH, Cho S, Lee CH. Enhanced cognitive effects of demethoxycurcumin, a natural derivative of curcumin on scopolamine-induced memory impairment in mice. Molecules, 21, 1022 (2016)

Lv J, Lu C, Jiang N, Wang H, Huang H, Chen Y, Li Y, Liu X. Protective effect of ginsenoside $\mathrm{Rh} 2$ on scopolamine-induced memory deficits through regulation of cholinergic transmission, oxidative stress and the ERK-CREB-BDNF signaling pathway. Phytother Res, 35, 337-345 (2020)

McGeer PL, Itagaki S, Boyes BE, McGeer EG. Reactive microglia are positive for HLA-DR in the substantia nigra of Parkinson's and Alzheimer's disease brains. Neurology, 38, 1285-1291 (1988)

Mentang F, Maita M, Ushido H, Ohshima T. Efficacy of silkworm (Bombyx mori L.) chrysalis oil as a lipid source in adult Wistar rats. Food Chem, 127, 899-904 (2011)

Oh JH, Choi BJ, Chang MS, Park SK. Nelumbo nucifera semen extract improves memory in rats with scopolamineinduced amnesia through the induction of choline acetyltransferase expression. Neurosci Lett, 461, 41-44 (2009)

Park JA, Jin KS, Lee JY, Kwon HJ, Kim BW. Antioxidative and anti-obesity activities of Tetrapanax papyriferus and Siegesbeckia pubescens extracts and their synergistic anti-obesity effects. Korean J Microbiol Biotechnol, 41, 341-349 (2013)

Park SB, Lee JH, Kim HD, Soe KH, Jeong HS, Kim DH, Lee SE. Screening of plant extracts with cholinesterase inhibition activity. Korean J Plant Res, 31, 433-452 (2018)

Ryu HS, Kim J, Kim HS. Enhancing effect of Sorghum bicolor L. Moench (Sorghum, su-su) extracts on mouse spleen and macrophage cell activation. Korean J Food Nutr, 19, 176-182 (2006)

Senechal Y, Kelly PH, Dev K. Amyloid precursor protein knockout mice show age-dependent deficits in passive avoidance learning. Behav Brain Res, 186, 126-132 (2008) 
Seo MC, Ko JY, Song SB, Lee JS, Kang JR, Kwak DY, Oh BG, Yoon YN, Nam MH, Jeong HS, Woo KS. Antioxidant compounds and activities of foxtail millet, proso millet and sorghum with different pulverizing methods. J Korean Soc Food Sci Nutr, 40, 790-797 (2011)

Shin EM, Zhou HY, Guo LY, Kim JA, Lee SH, Merfort I, Kang SS, Kim HS, Kim A, Kim YS. Antiinflammatory effects of glycyrol isolated from Glycyrrhiza uralensis in LPS-stimulated RAW264.7 macrophages. Int Immunopharmacol, 8, 1524-1532 (2008)

Singhal G, Jaehne EJ, Corrigan F, Toben C, Baune BT. Inflammasomes in neuroinflammation and changes in brain function: A focused review. Front Neurosci, 8, 315-328 (2014)

Son JH, Kim YS, Kim KH, Jeon BD, Kwon TD. Effects of silkworm pupae powder (Bombyx mori L.) intake and resistance exercise training on energy metabolism in mice. Korean J Sports Sci, 27, 1565-1573 (2018)

Sullivan AC, Pangloli P, Dia VP. Kafirin from Sorghum bicolor inhibition of inflammation in THP-1 human macrophages is associated with reduction of intracellular reactive oxygen species. Food Chem Toxicol, 111, 503510 (2018)
Sun J, Nan G. The extracellular signal-regulated kinase 1/2 pathway in neurological diseases: A potential therapeutic target (Review). Int J Molecul Med, 39, 1338-1346 (2017)

Tabet N. Acetylcholinesterase inhibitors for Alzheimer's disease: Anti-inflammatories in acetylcholine clothing. Age Ageing, 35, 336-338 (2006)

Talesa VN. Acetylcholinesterase in Alzheimer's disease. Mech Ageing Dev, 122, 1961-1969 (2001)

Woo KS, Seo MC, Kang JR, Ko JY, Song SB, Lee JS, Oh BG, Park GD, Lee YH, Nam MH, Jeong HS. Antioxidant compounds and antioxidant activities of the methanolic extracts from milling fractions of sorghum (Sorghum bicolor L. Moench). J Korean Soc Food Sci Nutr, 39, 1695-1699 (2010)

Zhao Z, Wand W, Guo H, Zhou D. Antidepressant-like effect of liquiritin from Glycyrrhiza uralensis in chronic variable stress induced depression model rats. Behav Brain Res, 194, 108-113 (2008)

Zou Y, Hu T, Shi Y, Liao S, Liu J, Mu L, Chen CYO. Silkworm pupae oil exerts hypercholesterolemic and antioxidant effects in high-cholesterol diet-fed rats. J Sci Food Agric, 97, 2050-2056 (2017) 